\title{
NADP-DEPENDENT ISOCITRATE DEHYDROGENASE OF Astyanax scabripinnis (PISCES, CHARACIDAE) FROM THREE ALTITUDES AT GRANDE STREAM, CAMPOS DO JORDÃO, SP
}

\author{
MUNIN, F. S., SCHWANTES, M. L., SCHWANTES, A. R. and MOREIRA-FILHO, O. \\ Universidade Federal de São Carlos, Departamento de Genética e Evolução, \\ C.P. 676, CEP 3565-905, São Carlos, SP, Brazil \\ Correspondence to: Flavia Simone Munin, Universidade Federal de São Carlos, Departamento de Genética e \\ Evolução, C.P. 676, CEP 3565-905, São Carlos, SP, Brazil, e-mail: flaviamunin@hotmail.com \\ Received October 4, 2002 - Accepted May 22, 2003 - Distributed May 31, 2004
}

(With 2 figures)

\begin{abstract}
Electrokinetic, thermic, and kinetic properties of products of NADP-dependent isocitrate dehydrogenase (IDHP; EC 1.1.1.42) loci of Astyanax scabripinnis (Pisces, Characidae) collected at three different altitudes (700 m, 1,800 m, and 1,920 m) of Grande Stream at Campos do Jordão, State of São Paulo, Brazil, were analyzed. Two IDHP bidirectionally divergent loci, a single skeletal muscle, the IDHP$A^{*}$, and a single liver $I D H P-B^{*}$, both polymorphic, were detected in the three different altitude populations. The variant allele * 128 at the $I D H P-A *$ locus, had its highest frequency detected in the $1,920 \mathrm{~m}$ population (0.494). Among the nine variant alleles detected at the IDHP-B* locus $(* 37, * 57, * 69, * 79, * 85$, $* 114, * 119, * 124$, and $* 140$ ), the *37 and 79 were detected only in $1,800 \mathrm{~m}$ population. Chi-square values showed that only the $700 \mathrm{~m}$ population is not in Hardy-Weinberg equilibrium for the IDHP-A* locus, while for the $I D H P-B^{*}$ locus, no population is. Homogeneity $\mathrm{Chi}^{2}$ test indicated that the populations are significantly different in their A and B phenotype frequencies. Wright's FST mean value ( 0.036 and $0.32, I D H P-A^{*}$ and $I D H P-B^{*}$, respectively) was 0.178 for the three altitude populations which means that $82 \%$ of total genetic diversity was found among individuals of each one of the populations. Stability at environmental temperatures $\left(16^{\circ}\right.$ to $\left.21^{\circ} \mathrm{C}\right)$, and apparent $K_{\mathrm{m}}$ and $V_{\max }$ values of each A-phenotype skeletal muscle crude extract suggest different roles of A-isoforms during the increased lipogenesis that occurs in fish at low temperatures.
\end{abstract}

Key words: Astyanax scabripinnis, NADP-dependent isocitrate dehydrogenase, allozymes, thermostability, altitudes.

\section{RESUMO}

\section{Isocitrato desidrogenase NADP-dependente de Astyanax scabripinnis (Pisces, Characidae) de diferentes altitudes do Ribeirão Grande, Campos do Jordão, SP}

Foram analisadas propriedades eletrocinéticas, térmicas e cinéticas dos produtos dos locos que codificam o isocitrato desidrogenase NADP-dependente (IDHP; E.C. 1.1.1.42) como Astyanax scabripinnis (Pisces, Characidae) em três diferentes alturas do Ribeirão Grande, Estado de São Paulo, Brasil. Nas populações das três altitudes foram detectados dois locos da IDHP, bidirecionalmente divergentes, um único em músculo esquelético, o $I D H P-A^{*}$, e um único em fígado, o $I D H P$ - $B^{*}$, ambos polimórficos. O único alelo variante no loco $I D H P-A^{*}, A^{*} 128$, mostrou maior frequiência na população de 1.920 $\mathrm{m}(0,494)$. Dentre os nove alelos variantes detectados no loco IDHP-B* $(* 37, * 57, * 69, * 79, * 85$, $* 114, * 119, * 124$ e *140), os alelos *37 e *79 apareceram somente na população de $1.800 \mathrm{~m}$. Valores de Qui-quadrado revelaram que para o loco $I D H P-A^{*}$ somente a população de $700 \mathrm{~m}$ não está em equilíbrio de Hardy-Weinberg, enquanto para o loco $I D H P-B^{*}$ nenhuma população se encontra em 
equilíbrio. Qui ${ }^{2}$ da homogeneidade revelou que as populações são significativamente diferentes em suas freqüências fenotípicas para ambos os locos. Valor médio de FST de Wright $(0,036$ e 0,320 , IDHP$A^{*}$ e $I D H P-B^{*}$, respectivamente) foi de 0,178 para populações das três altitudes, o que significa que $82 \%$ da diversidade gênica total foi detectada entre indivíduos da mesma população. Estabilidades em temperatura ambiente $\left(16^{\circ}\right.$ a $\left.21^{\circ} \mathrm{C}\right)$ e valores de $K_{\mathrm{m}}$ e $V_{\max }$ aparentes de extratos de músculo esquelético de cada fenótipo-A sugerem diferentes papéis das isoformas-A na lipogênese aumentada que ocorre nos peixes em baixas temperaturas.

Palavras-chave: Astyanax scabripinnis, isocitrato desidrogenase NADP-dependente, alozimas, termoestabilidade, altitudes.

\section{INTRODUCTION}

The dimeric enzyme isocitrate dehydrogenase found in all vertebrate cells in the Krebs cycle exists in two forms: one NAD (EC 1.1.1.41), and the other NADP-dependent (EC 1.1.1.42) (Lowenstein \& Smith, 1962). In the presence of a divalent cation $\left(\mathrm{Mn}^{2+}\right.$ or $\left.\mathrm{Mg}^{2+}\right)$ both forms catalyze the oxidative decarboxilation of isocitric acid to $\alpha$-ketoglutarate. The cytosolic NADP-dependent isocitrate dehydrogenase (IDHP) function is to provide NADPH for lipid biosynthesis, and $\alpha$-ketoglutarate for glutamate and glutamine formation (Saxrud et al., 1996). Multiple forms of IDHP encoded by unlinked gene loci have been described in fish (Allendorf et al., 1977; Van-Beneden et al., 1981; Perdices et al., 1996; Doadrio \& Carmona, 1998; Chiari \& Sodré, 1999; Kohlmann \& Kersten, 1999; Renesto et al., 2000).

The small characid fish Astyanax scabripinnis is excellent for evolutionary studies due to its remarkable karyotypic diversity, wide geographical distribution, presence of supernumerary B chromosome, and incidence of natural triploidy (Moreira-Filho \& Bertollo, 1991; Maistro et al., 1992; Fauaz et al., 1994). Based on the divergence of karyotypical numbers, variation in chromosome morphology, Cbanding patterns, and the location of NORs observed in seven populations of $A$. scabripinnis from Paranapanema, São Francisco, and Tiete rivers, MoreiraFilho \& Bertollo (1991) proposed the scabripinnis complex. The occurrence of genetic variation has also been shown in previous studies focused on six proteincoding loci within these populations of $A$. scabripinnis (Schwantes et al., 1994).

The present study is part of an integrated project entitled "Genetic Bases of Diversity in the scabripinnis complex". Its objective was to compare electrophoretic patterns, stability at environmental temperature $\left(16^{\circ}\right.$ to $21^{\circ} \mathrm{C}$ ), and some kinetic parameters of IDHP of A.scabripinnis populations from three different altitudes at Grande Stream, Campos do Jordão, SP, Brazil, in an attempt to distinguish these populations and determine if those parameters might confer adaptability of individuals to a particular habitat.

\section{MATERIAL AND METHODS}

Five hundred eighty-nine A. scabripinnis individuals caught at ponds located at three altitudes of Grande Stream were analyzed: 204 individuals from $700 \mathrm{~m} ; 210$ from 1,800 m; and 175 from 1,920 m. The water temperature and dissolved $\mathrm{O}_{2}$ measured at each altitude varied from $16^{\circ} \mathrm{C}$ and $10.4 \mathrm{mg} / \mathrm{ml}$ at $1,920 \mathrm{~m}$, to $18^{\circ} \mathrm{C}$ and $9.8 \mathrm{mg} / \mathrm{ml}$ at $1,800 \mathrm{~m}$, and $21^{\circ} \mathrm{C}$ and $9.5 \mathrm{mg} / \mathrm{ml}$ at $700 \mathrm{~m}$ (Landini et al., 2002). Liver and white muscle from each individual were dissected immediately after capture and kept at $-20^{\circ} \mathrm{C}$. A small piece of each tissue was homogenized (w/v) in $50 \mathrm{mM}$ phosphate potassium buffer $(\mathrm{pH} 7.0)$, using a Potter-Elvejhem tissue grinder, and then centrifuged at $27,000 \mathrm{~g}$ for $30 \mathrm{~min}$ at $4^{\circ} \mathrm{C}$ in a Sorvall RC5B centrifuge. The resulting crude extracts were used for electrophoretic and spectrophotometric analyses. Electrophoreses were carried out employing horizontal gels containing $14 \%(\mathrm{w} / \mathrm{v})$ corn starch prepared according to Val et al. (1981), using the $\mathrm{pH} 6.9$ Whitt (1970) buffer system. A voltage gradient of $5 \mathrm{~V} / \mathrm{cm}$ was applied for $12-14 \mathrm{~h}$ at $4^{\circ} \mathrm{C}$. After electrophoreses, the gels were sliced lengthwise and the lower halves incubated in an IDHP staining solution, described by Shaklee $e t$ al. (1989) and modified by us, consisting of $25.8 \mathrm{mM}$ isocitric acid, $0.218 \mathrm{mM}$ NADP, 0.456 mM PMS, 0.4 mM MTT, $0.1 \mathrm{mM} \mathrm{MgCl}, 1.5 \%$ agaragar, and a $100 \mathrm{~m}$ Tris-HCl pH 7.4 buffer. Nomenclature of IDHP gene loci and iso/allozymes was taken from Shaklee et al. (1990). Alleles were designated 
by numbers with $* 100$ representing the most frequent allele. Subsequent numbers refer to their relative mobility. Electrophoretic data were used in $\mathrm{Chi}^{2}$ homogeneity tests among the three different altitude populations and analyzed for Hardy-Weinberg equilibrium. A locus was considered polymorphic if the frequency of the most common allele was equal to or less than $0.99\left(P_{99}\right)$. The observed intralocus heterozygosity $(\mathrm{Ho})$ was obtained by direct counting. Expected intralocus heterozygosity $(\mathrm{He}$ ) was calculated according to Nei (1978). Deviations from random-mating expectations within populations were estimated for both loci using $F_{\text {is }}$ (Wright, 1978), and the statistical significance of each $F_{\text {is }}$ was tested using the relationship $\chi^{2}=N F_{\text {is }}^{2}$; d.f. $=(a-1)(s-1)$, where $\mathrm{N}$ is the total number of individuals sampled at the locus, $a$ is the number of alleles at the locus, and $s$ is the number of subpopulations (Nei, 1977). Genetic differentiation among populations was estimated as Wright's standardized variance in allele frequencies $\left(F_{\text {st }}\right)$ (Wright, 1978), and the significance of $F_{\text {st }}$ estimates was tested using the relationship with $\chi^{2}=$ $2 N F_{\mathrm{st}}+(a-1)$ with $(a-1)(\mathrm{s}-1)$ degrees of freedom (Workman \& Niswander, 1970).

Temperature dependency of both A-phenotypes (A100 and A128) of skeletal muscle (the IDHP-A is the single isoform in skeletal muscle) crude extracts was tested by subjecting each sample to several different temperatures, for $3 \mathrm{~min}$, in two ways. In the first test, glass tubes containing $10 \mu \mathrm{L}$ of extract of each phenotype were incubated at $25^{\circ}, 30^{\circ}, 35^{\circ}, 40^{\circ}$, $45^{\circ}, 50^{\circ}$, and $55^{\circ} \mathrm{C}$ in the presence of the coenzyme (0.18 mM NADP, $1 \mathrm{mM} \mathrm{MgCl}_{2}$, and $20 \mathrm{mM}$ Tris$\mathrm{HCl}$ buffer $\mathrm{pH} \mathrm{8.5)} \mathrm{for} 3 \mathrm{~min}$. Immediately afterward, their residual activities were examined at $25^{\circ} \mathrm{C}$ through the change in absorbance at $340 \mathrm{\eta m}$ in an HP-8452A diode array spectrophotometer using a temperaturecontrolled cuvette holder. In the second test, extracts of each phenotype were incubated in the spectrophotometer thermocell at $10^{\circ}, 15^{\circ}, 20^{\circ}, 25^{\circ}, 30^{\circ}, 40^{\circ}$, and $50^{\circ} \mathrm{C}$, according to Williamson (1998). In both cases, the reactions were triggered by addition of the substrate (23 $\mu \mathrm{M}$ isocitric acid).

The kinetic parameters of IDHP were determined at $25^{\circ} \mathrm{C}$ by measuring NADP reduction at 340 $\eta \mathrm{m}$ for $3 \mathrm{~min}$, according to Williamson (1998). The assays were carried out in a $20 \mathrm{mM}$ Tris- $\mathrm{HCl}$ buffer $\mathrm{pH} 8.5$ containing $0.18 \mathrm{mM}$ NADP, $1 \mathrm{mM} \mathrm{MgCl}$, and varying concentrations of isocitrate $(288 \mathrm{~nm}$ to $23 \mu \mathrm{m})$. All assays were performed in triplicate and initiated by adding $10 \mu \mathrm{L}$ of enzyme (crude extract) to $1.0 \mathrm{ml}$ of assay medium. Apparent Michaelis-Menten constants $\left(K_{\mathrm{m}}\right)$ and maximum catalytic rates $\left(V_{\max }\right)$ were calculated by the Lineweaver Burk method using double-reciprocal plots of velocity vs. substrate concentrations.

Statistical differences among thermal stability, and $K_{\mathrm{m}}$, and $V_{\max }$ values detected in skeletal muscle crude extracts of $A$. scabripinnis A-phenotypes were determined by the non-parametric Kruskal-Wallis (Sokal \& Rohlf, 1981) and Mann-Whitney tests (Zar, 1974) with a probability level of 0.05 chosen as the limit of statistical significance.

\section{RESULTS}

Electrophoretic patterns of $A$. scabripinnis IDHP collected at $700 \mathrm{~m} ; 1,800 \mathrm{~m}$; and 1,920 m of Grande Stream at Campos do Jordão, showed two bidirectionally divergent loci, the skeletal muscle-single IDHP- $A^{*}$, and the liver-single IDHP$B^{*}$, both polymorphic (Fig. 1; Table 1).

Fig. 1A shows the three IDHP-A* phenotypes, detected in skeletal muscle of the populations from the three altitudes due to the presence of a $* 128$ variant allele. The highest frequency of this variant allele was detected in the $1,920 \mathrm{~m}$ population $(0.494)$ (Table 1). Chi-square $\left(\chi^{2}\right)$ values obtained indicate that only the $700 \mathrm{~m}$ population were not in Hardy-Weinberg genetic equilibrium (HWE) for the IDHP- $A$ * locus, as indicated by the significantly different genotypic frequencies (Table 2). Figure 1B shows the twentyone $I D H P-B^{*}$ phenotypes detected in these individuals due to the presence of nine variant alleles: $* 37, * 57$, $* 69, * 79, * 85, * 114, * 119, * 124$, and *140. The 700 $\mathrm{m}$ population was fixed for six of these eight variant alleles: *57, *69,*85,*119,*124, and *140 (Table 1). The specimens collected from $1,800 \mathrm{~m}$ were fixed for six among the eight variant alleles: *37, *57, *69, $* 79$, *85, and *114 (Table 1). The specimens collected from $1,920 \mathrm{~m}$ were fixed for seven of the variant alleles: $* 57, * 69, * 85, * 114, * 119, * 124$, and *140 (Table 1). The $\chi^{2}$ values obtained (Table 2) indicate that the three altitude populations are not in HWE for this locus. Among these variant alleles two altitude-exclusive alleles were detected: the $* 37$ and $* 79$, in $1,800 \mathrm{~m}$ population.

Homogeneity $\mathrm{Chi}^{2}$ test indicated that the populations are significantly different in their A and B phenotype frequencies (Table 3 ). 


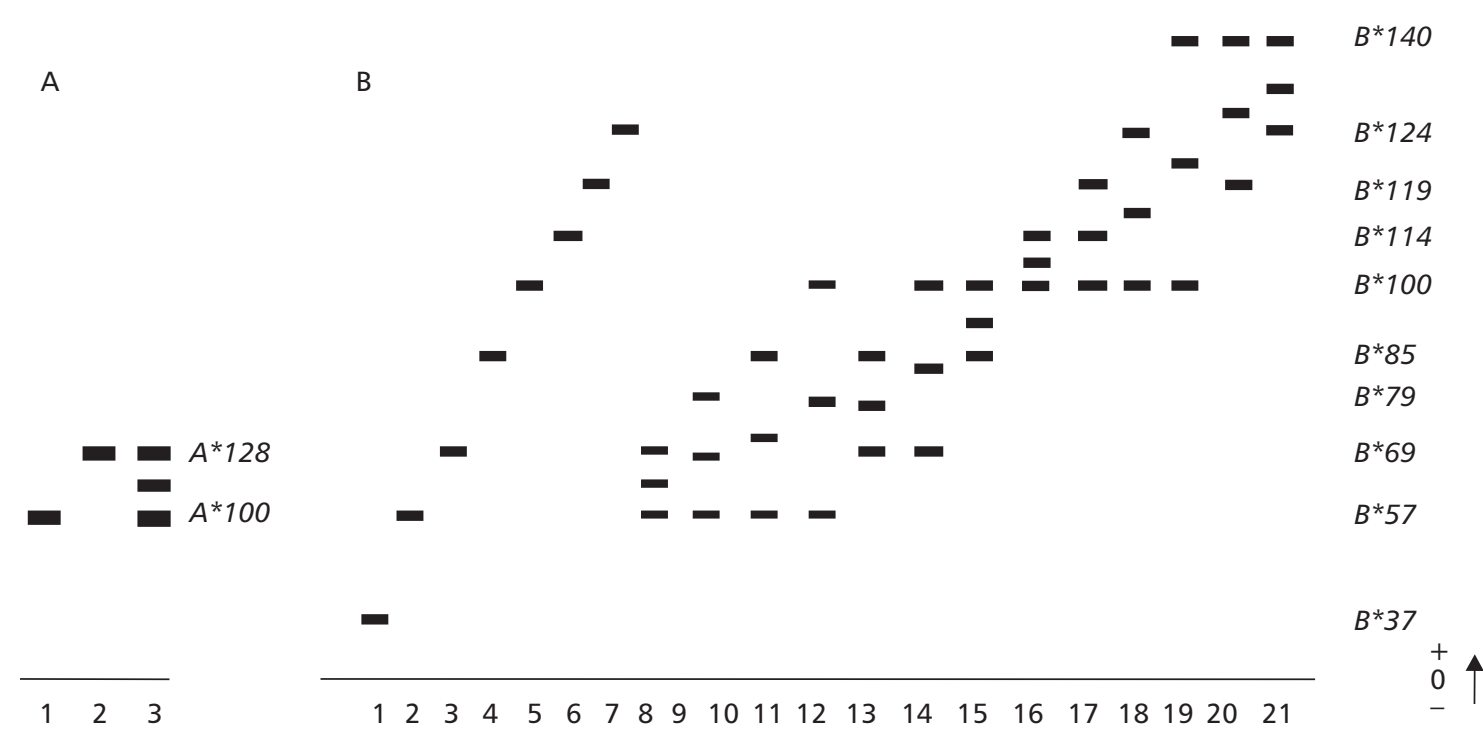

Fig. 1 - Schematic representation of IDHP phenotypes detected in populations of $A$. scabripinnis and their genetic interpretation. (A) skeletal muscle, and (B) liver extracts. A: 1. A100; 2. A128; 3. A100/128. B: 1. B37; 2. B57; 3. B69; 4. B85; 5. B100; 6. B124; 7. B140; 8. B57/69; 9. B57/79; 10. B57/85; 11. B57/100; 12. B69/85; 13. B69/100; 14. B85/100; 15. B85/140; 16. $\mathrm{B} 100 / 114 ; 17$. B100/124; 18. B100/140; 19. B124/140.

TABLE 1

Allelic frequencies observed at $I D H P-A$ * and $I D H P-B$ * loci from $A$. scabripinnis collected from three altitudes.

\begin{tabular}{|c|c|c|c|}
\hline \multicolumn{4}{|c|}{ Altitude populations } \\
\hline & $700 \mathrm{~m}$ & $1,800 \mathrm{~m}$ & $1,920 \mathrm{~m}$ \\
\hline \multicolumn{4}{|c|}{$I D H P-A^{*}$} \\
\hline 100 & 0.725 & 0.617 & 0.506 \\
\hline 128 & 0.275 & 0.383 & 0.494 \\
\hline \multicolumn{4}{|c|}{$I D H P-B^{*}$} \\
\hline 37 & 0 & 0.008 & 0 \\
\hline 57 & 0.049 & 0.212 & 0.100 \\
\hline 69 & 0.303 & 0.242 & 0.150 \\
\hline 79 & 0 & 0.031 & 0 \\
\hline 85 & 0.227 & 0.212 & 0.250 \\
\hline 100 & 0.340 & 0.292 & 0.417 \\
\hline 114 & 0 & 0.003 & 0.044 \\
\hline 119 & 0.032 & 0 & 0.027 \\
\hline 124 & 0.039 & 0 & 0.006 \\
\hline 140 & 0.010 & 0 & 0.006 \\
\hline
\end{tabular}

Table 2 shows a deficit of heterozygotes for both $I D H P-A^{*}(H o=0.235, H e=0.398$ for 700 $\mathrm{m} ; H o=0.471, H e=0.473$ for $1,800 \mathrm{~m} ; H o=0.440$,
$H e=0.500$ for $1,920 \mathrm{~m})$ and $I D H P-B^{*}(H o=0.305$, $H e=0.736$ for $700 \mathrm{~m} ; H o=0.477, H e=0.765$ for $1,800 \mathrm{~m} ; H o=0.500, H e=0.729$ for $1,920 \mathrm{~m}$ ) loci 
of the three populations. $F_{\text {is }}$ values (Table 4 ) showed for both loci, a $16.4 \%$ and $16.9 \%$ heterozygote deficiency. $F_{\text {it }}$ mean value $(0.314)$ showed a $31.4 \%$ heterozygote deficiency in total population. Wright's $F_{\text {st }}$ mean value was 0.178 ( 0.036 and 0.32 for IDHP$A^{\text {st }}$ and $I D H P-B^{*}$ loci, respectively) among the 3 sampled populations, i.e., $17.8 \%$ of the total gene diversity $\left(H_{\mathrm{t}}=0.615\right)$ was attributed to differences between populations. The remaining gene diversity $(1-0.178=0.822)$ was due to within-total population variability.

Fig. 2 shows temperature dependency of both homozygous phenotypes detected for the IDHP-A* of $A$. scabripinnis. When both isoforms were exposed to $25^{\circ}, 30^{\circ}, 35^{\circ}, 40^{\circ}, 45^{\circ}, 50^{\circ}$, and $55^{\circ} \mathrm{C}$, its response was significantly different $(\mathrm{p}=0.0265)$. While the $A * 128$-isoform showed maximum activity when incubated at $35^{\circ} \mathrm{C}$, the $A * 100$ did so at $45^{\circ} \mathrm{C}$ (Fig. 2A). When extracts of each phenotype were incubated in the spectrophotometer thermocell at $10^{\circ}, 15^{\circ}, 20^{\circ}, 25^{\circ}, 30^{\circ}, 40^{\circ}$, and $50^{\circ} \mathrm{C}$, both isoforms increased their activities (Fig. 2B), but in the physiological temperature interval of the three altitude populations $\left(16^{\circ}\right.$ to $\left.2^{\circ} \mathrm{C}\right)$ (Landini et al. $2002)$, significant differences between them ( $\mathrm{p}=$ 0.0286 ) were detected. While $A * 100$-isoform chan- ged its residual activity from $6 \%$ to $15 \%$, the $A * 128$ isoform changed from $16 \%$ to $35 \%$.

In order to compare the effect of substrate ( 288 $\eta \mathrm{m}$ to $23 \mu \mathrm{m}$ ) concentrations on IDHP activity, we examined the responses of the apparent $\mathrm{Km}$ and $V_{\text {max }}$ of isocitrate on both A-phenotype skeletal muscle extracts. The $K_{\mathrm{m}}$ and $V_{\max }$ values obtained for the A128 phenotype extracts $\left(K_{\mathrm{m}}=0.109 \times 10^{-5} \mathrm{M} ; V_{\max }=\right.$ $62 \times 10^{-9}$ moles $\left.\times \operatorname{liter}^{-1} \times \mathrm{min}^{-1}\right)$ were higher than those obtained for the $\mathrm{A} 100\left(K_{\mathrm{m}}=0.037 \times 10^{-5} \mathrm{M}\right.$; $V_{\text {max }}=25 \times 10^{-9}$ moles $\times$ liter $\left.^{-1} \times \min ^{-1}\right)$. However, these differences are not significantly different $(\mathrm{p}=$ $0.1297)$.

\section{DISCUSSION}

The IDHP bidirectionally divergent loci detected in A. scabripinnis have also been described in other fish (Perdices et al., 1996; Chiari \& Sodré, 1999; Kohlmann \& Kersten, 1999; Renesto et al., 2000). In the fish species Fundulus heteroclitus (VanBeneden et al., 1981) and in the genus Leuciscos (Doadrio \& Carmona, 1998), 3 IDHP loci, 2 liverspecific and 1 skeletal muscle-specific, were described. In rainbow trout, muscle and liver forms are codified by 4 loci (Allendorf et al., 1977).

TABLE 2

$\mathrm{Chi}^{2}$ analysis for Hardy-Weinberg equilibrium, observed and expected heterozygosities for IDHP loci from A. scabripinnis from three altitudes. $N$ - sample size, d.f. - degrees of freedom, $\mathrm{Ho}$ - observed intralocus heterozygosity, $\mathrm{He}$ - expected intralocus heterozygosity.

\begin{tabular}{|c|c|c|c|c|c|}
\hline $\begin{array}{c}\text { Altitude } \\
(N)\end{array}$ & $\begin{array}{c}\text { Number of } \\
\text { alleles }\end{array}$ & $\chi^{2}$ & d.f. & Ho & $\mathrm{He}$ \\
\hline \multicolumn{6}{|c|}{ IDHP-A* } \\
\hline $\begin{array}{l}700 \mathrm{~m} \\
(204)\end{array}$ & 2 & $34.170 * *$ & 1 & 0.235 & 0.398 \\
\hline $\begin{array}{c}1800 \mathrm{~m} \\
(210)\end{array}$ & 2 & 0.002 & 1 & 0.471 & 0.473 \\
\hline $\begin{array}{c}1920 \mathrm{~m} \\
(175)\end{array}$ & 2 & 2.515 & 1 & 0.440 & 0.500 \\
\hline \multicolumn{6}{|c|}{$I D H P-B *$} \\
\hline $\begin{array}{l}700 \mathrm{~m} \\
(204)\end{array}$ & 7 & $49.745^{* *}$ & 1 & 0.305 & 0.736 \\
\hline $\begin{array}{c}1800 \mathrm{~m} \\
(210)\end{array}$ & 7 & $45.401 * *$ & 1 & 0.477 & 0.765 \\
\hline $\begin{array}{c}1920 \mathrm{~m} \\
(175)\end{array}$ & 8 & $10.230 *$ & 1 & 0.500 & 0.729 \\
\hline
\end{tabular}

$* \mathrm{p}<0.05 ; * * \mathrm{p}<0.001$ 
TABLE 3

Homogeneity $\mathrm{Chi}^{2}$ tests for comparing the IDHP phenotype frequencies detected in the three altitude populations.

\begin{tabular}{|c|c|c|c|c|}
\hline & $\begin{array}{l}700 \mathrm{~m} \mathrm{x} \\
1,800 \mathrm{~m}\end{array}$ & $\begin{array}{l}700 \mathrm{~m} \mathrm{x} \\
1,920 \mathrm{~m}\end{array}$ & $\begin{array}{c}1,800 \mathrm{~m} \mathrm{x} \\
1,920 \mathrm{~m}\end{array}$ & $\begin{array}{c}700 \mathrm{~m} \times 1,800 \mathrm{~m} \times \\
1,920 \mathrm{~m}\end{array}$ \\
\hline \multicolumn{5}{|c|}{$I D H P-A *$} \\
\hline$\chi^{2}$ & $30.76^{* *}$ & $49.09 * *$ & $10.66^{*}$ & $62.7 * *$ \\
\hline d.f. & 2 & 2 & 2 & 4 \\
\hline \multicolumn{5}{|c|}{$I D H P-B *$} \\
\hline$\chi^{2}$ & $16.29 *$ & $11.84^{*}$ & $12.49 *$ & $25.56^{*}$ \\
\hline d.f. & 4 & 4 & 4 & 8 \\
\hline
\end{tabular}

$* \mathrm{p}<0.05 ; * * \mathrm{p}<0.001$.

TABLE 4

Wright's $F$-statistics analyses (Wright, 1978) for both IDHP loci for $A$. scabripinnis from three altitudes.

\begin{tabular}{|l|c|c|c|c|c|c|c|c|c|c|}
\hline & $\boldsymbol{F}_{\text {is }}$ & $\chi^{\mathbf{2}} \boldsymbol{F}_{\text {is }}$ & d.f. & $\boldsymbol{F}_{\text {it }}$ & $\boldsymbol{F}_{\text {st }}$ & $\chi^{2} \boldsymbol{F}_{\text {st }}$ & d.f. & $\boldsymbol{H}_{\mathbf{i}}$ & $\boldsymbol{H}_{\mathbf{s}}$ & $\boldsymbol{H}_{\mathbf{t}}$ \\
\hline$I D H P-A^{*}$ & 0.164 & $15.862 *$ & 2 & 0.194 & 0.036 & $42.243^{*}$ & 2 & 0.382 & 0.457 & 0.474 \\
\hline$I D H P-B^{*}$ & 0.169 & 12.006 & 18 & 0.435 & 0.320 & 2,436 & 18 & 0.427 & 0.514 & 0.756 \\
\hline
\end{tabular}

Wright's $F_{\text {is }}$ fixation index measures the deviation of genotypic frequencies from the HWE of individuals relative to its subpopulaton. Wright's $F_{\text {it }}$ fixation index measures the deviation of genotypic frequencies from the Hardy-Weinberg equilibrium of individuals relative to the total populaton. Wright's $F_{\mathrm{st}}$ fixation index measures the degree of heterogeneity among populations. $* \mathrm{p}<0.001$

The polymorphism at the IDHP loci here detected was also detected in other fish (Perdices et al., 1996; Doadrio \& Carmona, 1998; Chiari \& Sodré, 1999; Kohlmann \& Kersten, 1999; Renesto et al., 2000 ). Only the $I D H P-A^{*}$ genotypic frequencies of the $1,800 \mathrm{~m}$ and $1,920 \mathrm{~m}$ populations did not differ from Hardy-Weinberg expectations. The IDHP-A* genotypic frequencies from the $700 \mathrm{~m}$ population, as well as the $I D H P-B^{*}$ genotypic frequencies from the three altitude populations differed from HardyWeinberg expectations. In cases where the genotypic frequencies did not differ from HWE for more than one sample of a population, it could be suggested that each sample represented either an independent subpopulation within which mating was random or was a random sample from a larger panmictic unit (Carvalho, 1993). Except for the IDHP-A* genotypic frequencies of $1,800 \mathrm{~m}$ and $1,920 \mathrm{~m}$ populations, this is not applicable to our sample. According to Chiari \& Sodré (1999), divergences from Hardy-Weinberg equilibrium in the expected genotypic frequencies may occur due to mutation, natural selection, assortative mating, loss or gain of migrants, genetic drift, and/or methodological errors.
One of the reasons for the significant heterogeneity obtained when IDHP loci of the three $A$. scabripinnis altitude populations were compared by homogeneity chi-square tests could be the existence of variant alleles detected in only one of the populations. Since these analyzed populations are relatively small, genetic drift could be responsible for disappearance/maintenance of these alleles. Meanwhile, the existence of alleles found in specific populations and lack of homogeneity in their A and B phenotype frequencies suggest a reduced or nonexistent gene flow among these groups, characterizing populations in an isolating process. According to Avise et al. (1986), if localized fish populations inhabit similar environments or remain interconnected through migration and gene flow, they may display largely homogeneous arrays of phenotypic or genetic traits. If, however, they are exposed to contrasting environmental conditions and/or exchange only a few migrants (Stephen \& McAndrew, 1990), appreciable population differentiation may arise. As most of the variant alleles were found to occur at low frequencies in the populations, genetic drift could easily result in low levels of variation. 

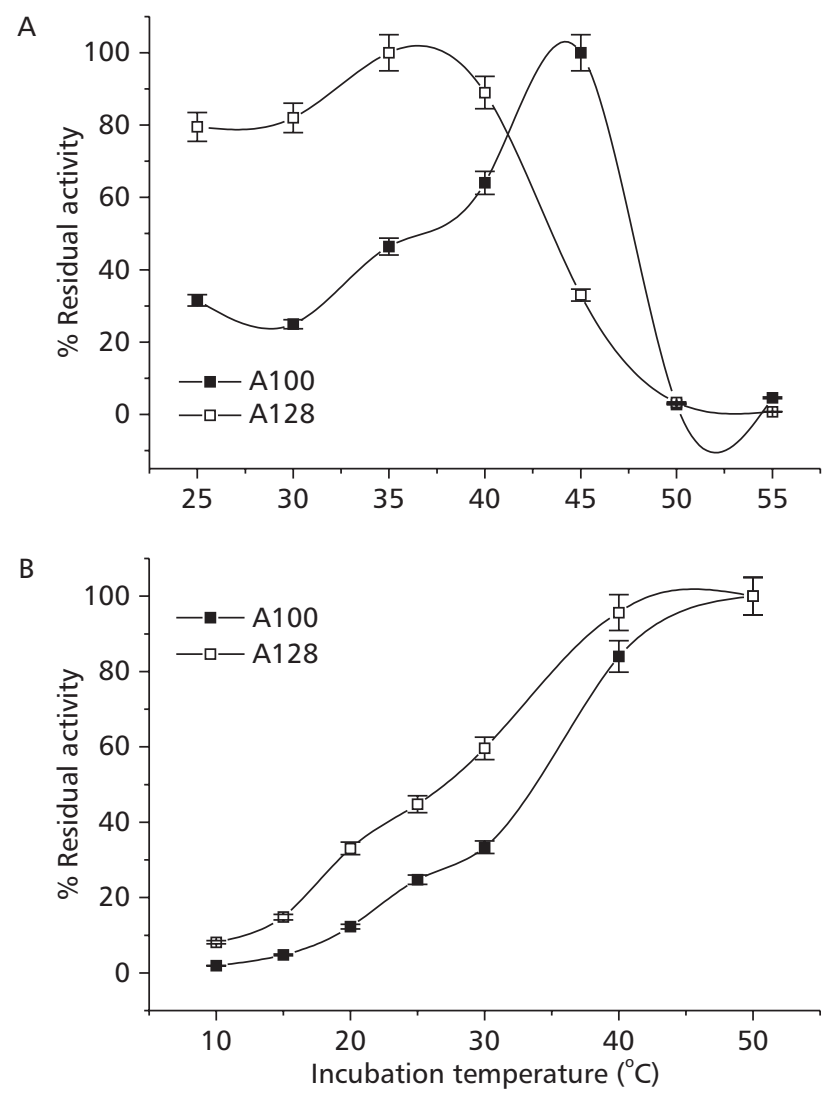

Fig. 2 - Temperature dependency of homozygous phenotypes detected for the IDHP- $A *$ of $A$. scabripinnis. A - extracts of each phenotype were incubated at $25^{\circ}, 30^{\circ}, 35^{\circ}, 40^{\circ}, 45^{\circ}, 50^{\circ}$, and $55^{\circ} \mathrm{C}$ in the presence of coenzyme $\left(0.18 \mathrm{mM} \mathrm{NADP}, 1 \mathrm{mM} \mathrm{MgCl}_{2}\right.$, and $20 \mathrm{mM}$ Tris- $\mathrm{HCl}$ buffer $\mathrm{pH} 8.5$ ) for $3 \mathrm{~min}$ and their residual activities were examined at $25^{\circ} \mathrm{C}$. B - extracts of each phenotype were incubated in the spectrophotometer thermocell at $10^{\circ}, 15^{\circ}, 20^{\circ}, 25^{\circ}, 30^{\circ}, 40^{\circ}$, and $50^{\circ} \mathrm{C}$, for 3 min and their residual activities were examined at each one of their incubation temperatures. In both tests, reactions were started with addition of $23 \mu \mathrm{M}$ isocitric acid.

According to Crouau-Roy (1988), many studies like ours have shown significant levels of heterozygote deficiency in natural populations, but these deficiencies are usually observed in some allozymic loci and/or in only some samples of a species, while for other loci the genotypic proportions are in equilibrium. These differences could signify independence in the evolutive process and, consequently, reproductive isolation. According to Engelbrecht et al. (1997), fit to Hardy-Weinberg proportions is an important but not an absolute criterion for inferring the genetic nature of populations because several factors may contribute to achieving deviations of genotype frequencies from expected Hardy-Weinberg proportions. These include natural selection, small effective population, sampling error, and anthropogenic influence. A small effective population (as here analyzed) may result in a decrease in the number of alleles through selection and inbreeding. The isolation of populations because of human activity or natural conditions may increase the probability of mating between relatives. This in turn increases the frequency of homozygous individuals and decreases the frequency of heterozygous individuals compared with those that may be expected from random mating. Also, inadequate sampling may result in the inclusion of more than one population in a particular river, a situation referred to as the Wahlund effect (Wahlund, 1928) which could result in Hardy-Weinberg discrepancies.

Heterozygote deficiency was showed in our sample through the $F_{\text {is }}(16.7 \%), F_{\text {it }}(31.4 \%)$, and $F_{\text {st }}(17.8 \%)$ values. Only $17.8 \%$ of the total gene 
diversity was attributed to differences between populations, i.e., $82.2 \%$ of the remaining gene diversity was due to within-total population variability. According to Katoh \& Foltz (1994), the high genetic differentiation $\left(F_{\text {st }}=0.321\right)$ among populations of the fish Valencia hispanica, excluding the mixed population, suggests reduced gene flow, allowing populations to adapt to local environments. The population subdivision $\left(F_{\text {st }}=0.178\right)$ detected among $A$. scabripinnis populations indicates a interruption of genetic exchange among them.

Spatial variation has a central role in evolutionary biology, particularly in studies of population differentiation and speciation (Baumgartner, 1986). Clinal variation, a spatial gradient in the frequency of a gene, genotype, or phenotype (Endler, 1977), as here detected for the IDHP-A*128, is common in natural populations and is characteristic of secondary contact zones between divergent conspecific populations. Because many geographic clines involve a significant latitudinal difference in allele frequencies, some authors have concluded that varying environments in assorted geographic regions differentially selected individuals with specific enzyme phenotypes (Philipp et al., 1985). Because most of the species analyzed in these studies were ectothermic, the most obvious component of the environment which might exert differential selective pressure among geographic regions of different latitudes is temperature. Thermal stability of proteins of animals from various habitats is quite different (Klyachko \& Ozernyuk, 1998). Such stability in proteins of different species correlates with environmental temperature (Alexandrov, 1977; DeLuca et al., 1983; Swezey \& Somero, 1982). In the present case, the IDHP- $A * 128$ allele, which showed a spatial gradient in its frequency in $A$. scabripinnis collected at different altitudes $(0.275$ at $700 \mathrm{~m} ; 0.383$ at $1,800 \mathrm{~m}$; and 0.494 at 1,920$)$, seemed thermolabile at high temperatures (maximum activity at $35^{\circ} \mathrm{C}$ ), but in the over-all physiological temperature interval $\left(16^{\circ}-21^{\circ} \mathrm{C}\right)$ was more active than the IDHP-A*100 allele, predominant in all altitudes. On the other hand, apparent $K_{\mathrm{m}}$ values obtained for the product of this most common allele showed a substrate affinity threefold higher $\left(K_{\mathrm{m}}=0.037 \times 10^{-5} \mathrm{M}\right)$ than that of the $A * 128\left(K_{\mathrm{m}}=0.109 \times 10^{-5} \mathrm{M}\right)$.

In the light of Tetragonopterinae fossil records from Pleistocene prior to the Mantiqueira mountain lifting, the existence of the three-altitude common alleles here detected could be explained. Also, the results here obtained showing divergences from Hardy-Weinberg equilibrium for both loci, significant heterogeneity among the three altitude populations, altitude exclusive alleles, heterozygote deficiency, and $F_{\text {is }}$ estimates could suggest that these fishes constitute solitary populations with low gene flow among them and a reproductively isolating process.

The IDHP- $A * 100$ was the most frequent allele in the three altitude populations, with its highest frequency in the $700 \mathrm{~m}$ population $(0.725)$, where the water temperature was the highest $(21 \mathrm{C})$ and the dissolved $\mathrm{O}_{2}$ was the smallest $(10.4 \mathrm{mg} / \mathrm{L})$. Its product, the A100-isoform, showed maximum activity at $45^{\circ} \mathrm{C}$, and in the range of the Grande Stream physiological temperature, $6 \%$ to $15 \%$ of its maximal activity. Since its $K_{m}$ value was the lowest detected (highest affinity to substrate), the $I D H P-A * 100$ product may function to provide NADPH for biosynthetic reactions, like increased lipogenesis which occurs in fish at low temperatures (Knipprat \& Mead, 1968), and $\alpha$-ketoglutarate required for glutamate and glutamine formation.

The IDHP- $A * 128$ has its highest frequency in the $1,920 \mathrm{~m}$ population $(0.494)$, where water temperature was the lowest $\left(16^{\circ} \mathrm{C}\right)$ and dissolved $\mathrm{O}_{2}$ was the highest $(9.5 \mathrm{mg} / \mathrm{L})$. Its product, the A128isoform, showed maximum activity at $35^{\circ} \mathrm{C}$, and in the range of the Grande Stream physiological temperature, $16 \%$ to $35 \%$ of its maximal activity. Since its $\mathrm{K}_{\mathrm{m}}$ value was the highest detected (lowest affinity to substrate), the $I D H P-A * 128$ product may function as another and less efficient option for providing NADPH for biosynthetic reactions.

Acknowledgments - The authors wish to thank Dr. Alberto Carvalho Peret for helping in statistical analyses, Luis Henrique da Silva for helping to catch the fishes, and Dr. Paula Ann Matvienko-Sikar, who critically reviewed this manuscript. This work was supported by FAPESP and CNPq.

\section{REFERENCES}

\footnotetext{
ALEXANDROV, Y. Y., 1977, Cells, molecules and temperature. Springer-Verlag, Berlin.

ALLENDORF, F. W., MITCHEL, N. \& STAHL, G., 1977, Isozyme loci in brown trout (Salmo trutta L.): detection and interpretation from population data. Hereditas, 86: 179-190.

AVISE, J. C., HELFMAN, G. S., SAUNDERS, N. C. \& HALES, L. S., 1986, Mitochondrial DNA differentiation in North Atlantic eels: population genetics consequences of an unusual life history pattern. Proc. Nat. Acad. Sci., USA, 83: 43504354.
} 
BAUMGARTNER, J. V., 1986, The genetics of differentiation in a stream population of the threespine stickleback, Gasterosteus aculeatus. Heredity, 57: 199-208.

CARVALHO, G. R., 1993, Evolutionary aspects of fish distributions: genetic variability and adaptation. J. Fish Biol., 43: 53-73.

CHIARI, L. \& SODRÉ, L. M. K., 1999, Genetic variability in five species of Anostomidae (Ostariophysi - Characiformes). Genet. Mol. Biol., 22: 517-523.

CROAU-ROY, B., 1988, Genetic structure of cave-dwelling beetle populations: significant deficiencies of heterozygotes. Heredity, 60: 321-327.

DE-LUCA, P. H., SCHWANTES, M. L. B. \& SCHWANTES, A. R., 1983, Adaptative features of ectothermic enzymes. IV. Studies on malate dehydrogenase of Astyanax fasciatus (Characidae) from Lobo Reservoir (São Carlos, São Paulo, Brasil). Comp. Biochem. Physiol., 47B: 315-324.

DOADRIO, I. \& CARMONA, J. A., 1998, Genetic divergence in Greek populations of the genus Leuciscos and its evolutionary and biogeographical implications. J. Fish Biol., 53: 591-613.

ENDLER, J. A., 1977, Geographical variation, speciation and clines. Princeton University Press, Princeton.

ENGELBRECHT, G. D., VAN DER BANK, F. H. \& MULDER, P. F. S., 1997, Allozyme variation in Schilbe intermedius Rüpel, 1832 (Pisces-Siluriformes) from two localities in the Limpopo River System, South Africa. Comp. Biochem. Physiol., $117 B(2)$ : 179-184.

FAUAZ, G., VICENTE, V. E. \& MOREIRA-FILHO, O., 1994, Natural triploidy and B chromosomes in the Neotropical fish genus Astyanax (Characidae). Rev. Brasil. Genet., 17: 157-163.

KATOH, M. \& FOLTZ, D. W., 1994, Genetic subdivision and morphological variation in freshwater snail species complex formerly referred to as Viviparus georgianus (Vea). Biol. $J$. of the Linnean Soc., 53: 73-90.

KLYACHKO, O. S. \& OZERNYUK, N. D., 1998, Functional and structural properties of lactate dehydrogense from embryos of different fishes. Comp. Biochem. Physiol., 119B(1): 77-80.

KNIPPRATH, W. G. \& MEAD, J. F. Lipids, 3: 121, 1968. In MOON, T. W. \& HOCHACHKA, P. W., 1971, Isocitrate dehydrogenases in rainbow trout liver. Biochem. J., 123: 695-705.

KOHLMANN, K. \& KERSTEN, P., 1999, Genetic variability of German and foreign common carp (Cyprinus carpio L.) populations. Aquaculture, 173: 435-445.

LANDINI, G. F., SCHWANTES, A. R. \& SCHWANTES, M. L. B., 2002, Astyanax scabripinnis (Pisces: Characidae) hemoglobins: structure and function. Braz. J. Biol., 62(4A): 595-599.

LOWENSTEIN, J. M. \& SMITH, S. R., 1962, Intra e extramitochondrial isocitrate dehydrogenase. Biochem. Biophys. Acta, 56: 385.

MAISTRO, E. L., FORESTI, F., OLIVEIRA, C. \& ALMEIDATOLEDO, L. F., 1992, Occurrence of macro B chromosomes in Astyanax scabripinnis paranae (Pisces, Characiformes, Characidae). Genetica, 87: 101-106.
MOREIRAFILHO, O. \& BERTOLLO, L. A. C., 1991, Astyanax scabripinnis (Pisces Characidae): A species complex. Rev. Bras. Genet., 14(2): 331-357.

NEI, M., 1978, Estimation of average heterozygosity and genetic distance from a small number of individuals. Genetics, 89: 583-590.

NEI, M., 1977, F-statistics and analysis of gene diversity in subdivided populations. Ann. Hum. Genet., 41: 225-233.

PERDICES, A., MACHORDOM, A. \& DOADRIO, I., 1996, Allozymic variation and relationships of the endangered cyprinodontid genus Valencia and its implications for conservation. J. Fish Biol., 49: 1112-1127.

PHILIPP, D. P., CHILDERS, W. F. \& WHITT, G. S., 1985 , Correlations of allele frequencies with physical and environmental variables for populations of largemouth bass, Micropterus salmoides (Lacepede). J. Fish Biol., 7: 347-365.

RENESTO, E., ZAWADZKI, C. H. \& REVALDARES, E., 2000, Genetic evidence for two species of the genus Pimelodus Lacépède, 1803 (Siluriformes, Pimelodidae) in the Iguaçu River (Brazil). Gen. Mol. Biol., 23: 809-813.

SAXRUD, K. M., LAMBETH, D. O. \& ANDERSON, P. M., 1996, Isocitrate dehydrogenases from Squalus acanthias (Spiny Dogfish) and citrate formation by isolated mitochondria. J. Exp. Zool., 274: 334-345.

SHAKLEE, J. B., ALLENDORF, F. W., MORIZOT, D. F. \& WHITT, G. S., 1989, Genetic Nomenclature for protein coding loci in fish: Proposed guildlines. Transac. Amer. Fish. Soc., 118: 218-227.

SHAKLEE, J. B., ALLENDORF, F. W., MORIZOT, D. C. F. \& WHITT, G. S., 1990, Gene nomenclature of protein-coding loci in fish. Trans. Am. Fish. Soc., 119: 2-15.

SCHWANTES, M. L., SCHWANTES, A. R. \& MOREIRAFILHO, O., 1994, Variabilidade protéica no complexo Astyanax scabripinnis (Pisces, Characidae) de diferentes bacias hidrográficas. In: 40ำ Congresso Nacional de Genética. Caxambu, MG.

SOKAL, R. R. \& ROHLF, F. J., 1981, Biometry. Freeman, San Francisco.

STEPHEN, A. B. \& McANDREW, B. J., 1990, Distribution of genetic variation in brown trout, Salmo trutta L., in Scotland. Aquac. Fish. Manag., 21: 47-66.

SWEZEY, R. R. \& SOMERO, G. N., 1982, Polymerization thermodynamics and structural stabilities of skeletal muscle actins from vertebrate adapted to different temperatures and hydrostatic pressures. Biochem., 21: 4496-4503.

VAL, A. L., SCHWANTES, A. R., SCHWANTES, M. L. B. \& DE LUCA, P. H., 1981, Amido hidrolizado de milho como suporte eletroforético. Ciência e Cultura, 33: 737-741.

VAN BENEDEN, R. J., CASHON, R. E. \& POWERS, D. A., 1981, Biochemical Genetics of Fundulus heteroclitus (L.). III. Inheritance of Isocitrate Dehydrogenase (IDH-A and IDHB), 6-Phosphogluconate Dehydrogenase (6-Pgdh-A), and Serum Esterase (Est-S) Polymorphisms. Biochem. Genet., 19: 701-714.

WAHLUND, S., 1928, Zuzammensetzung von populationen und korrelationserscheinungen vom standpunkt der vererbungslehre aus betrachtet. Hereditas, 11: 65-106. 
WHIT, G. S., 1970, Genetic variation of supernatant and mitochondrial malate dehydrogenase isozymes in teleost Fundulus heteroclitus. Experientia, 26: 734-736.

WILLIAMSON, J. H., 1998, Isocitrate dehydrogenase as a model system for undergraduate research projects. bio.davidson.edu/ Biology/ Jowiliamson/ Techniques/ ProtocolIntro.html.

WORKMAN, P. L. \& NISWANDER, J. D., 1970, Population studies on southwestern Indian Tribes II. Local genetic differentiation in the Papago. Amer. J. Hum. Genet., 22: 24-29
WRIGHT, S., 1978, Evolution and the genetics of population. Vol 4. Variability among and within natural populations. University of Chicago Press, Chicago.

ZAR, J. H., 1974, Bioestatistical Analysis. Prentice-Hall, New Jersey. 